\title{
Combining Ability and Gene Action Studies in Pearl Millet using Line x Tester Analysis under Arid Conditions
}

\author{
Kana Ram Kumawat ${ }^{1}$, P.C. Gupta ${ }^{2}$ and N.K. Sharma ${ }^{3}$ \\ ${ }^{1}$ Department of Genetics and Plant Breeding, College of Agriculture, ${ }^{2}$ Agricultural Research \\ Station and ${ }^{3}$ Institute of Agri Business Management, Swami Keshwanand Rajasthan \\ Agricultural University, Bikaner, Rajasthan-334006, India \\ *Corresponding author
}

\section{Keywords}

Combining ability, gene action, Pearl millet, Line $\times$ tester analysis, Crosses, Yield

Article Info

Accepted:

10 March 2019

Available Online:

10 April 2019

\section{A B S T R A C T}

Present investigation was carried out to study combining ability along with inheritance of grain yield and its component traits in 50 hybrids of pearl millet which were generated through line $\mathrm{x}$ tester mating design using 5 male sterile lines and 10 restorers as parental material at ICRISAT, Hyderabad during Summer, 2018. These hybrids were evaluated in randomized block design with 3 replications in 3 environments during Kharif, 2018 at Agricultural Research Station, Bikaner. In results, both GCA and SCA variances were found significant for majority of characters. The ratio of GCA and SCA variance indicated the predominance of non-additive gene action for all the characters studied. GCA effects revealed that parents like ICMA 843-22, RMS 7A (female), BIB-423, BIB-343, BIB-451 and BIB-407 (male) were good general combiners for grain yield and some contributing characters. On the basis of SCA effects the crosses namely RMS 7A x BIB-407, ICMA 843-22 x BIB-343, ICMA 843-22 x BIB-451, ICMA 88004 x BIB-423 and ICMA $93333 \times$ BIB-439 were identified as superior for seed yield and related traits over the environments. Therefore these parents and hybrids are recommended for utilization in development of promising hybrids as well as their use in population improvement.

\section{Introduction}

Pearl millet [Pennisetum glaucum (L.) R. Br.], which is also known as cat tail, spiked tail, bulrush millet and bajra is quick growing short duration crop having high tillering, drought and heat tolerance and well adapted to different type of soils. It is traditionally grown as rainfed crop mostly under low fertility and rainfall conditions. However, it also responds well to irrigation and improved management conditions. As a food grain, its grain possesses the highest amount of calories per 100 gram (Burton et al., 1972), which is mainly supplied by carbohydrates, fats and proteins (Flech, 1981). It is extensively cultivated as dual purpose crop over large areas in many countries including India. Pearl millet being a $\mathrm{C}_{4}$ plant species has high photosynthetic efficiency and dry matter production. Its plants are highly heterozygous because of its cross-pollinating nature due to 
protogyny. When the most widely used cytoplasmic male sterile line, Tift 23A, was released (Burton, 1965) it speed up the improvement work in pearl millet. The choice of right type of parent is a crucial step for a plant breeder which requires extensive and detailed genetical studies of existing germplasm as well as newly evolved promising lines. The combining ability provides guideline to a plant breeder in selecting the elite parents and desirable crosses to be used in formulation of systematic breeding programme and provides means of understanding the nature of gene action involved in the inheritance of various characters. With this perspective, the present investigation was carried out to estimate the combining ability variances and effects in crosses along with study of various components of genetic variation and to suggest suitable breeding strategy for improvement of yield under various environments with special respect to arid conditions.

\section{Materials and Methods}

The experimental material for present study consisted of 5 male sterile lines (RMS 7A from Rajasthan Agricultural Research Institute, Jaipur, Rajasthan and ICMA 843-22, ICMA 88004, ICMA 93333 and ICMA 97111 from The International Crops Research Institute for the Semi-Arid Tropics, Hyderabad) and 10 testers (BIB-343, BIB359, BIB-383, BIB-391, BIB-399, BIB-407, BIB-415, BIB-423, BIB-439 and BIB-451 which were collected from AICRP on Pearl Millet, Bikaner, Rajasthan). The 50 crosses were generated using line $\mathrm{x}$ tester mating design at International Crop Research Institute for the Semi-Arid Tropics (ICRISAT), Hyderabad during Summer, 2018. These hybrids were grown in randomized block design with three replications in three environments created by differentiating number of irrigations (The environment $\mathrm{E}_{1}, \mathrm{E}_{2}$ and $E_{3}$ were provided three, two and one irrigations, respectively) at Agricultural Research Station, Bikaner during Kharif, 2018. Each plot consisted of two rows each of 4 meter length with row spacing of $60 \mathrm{~cm}$ and plant to plant spacing of $15 \mathrm{~cm}$. All recommended cultural practices were followed to raise good crop. The observations were recorded on twelve morphological characters namely days to $50 \%$ flowering, days to maturity, plant height $(\mathrm{cm})$, total number of tillers per plant, number of effective tillers per plant, flag leaf area $\left(\mathrm{cm}^{2}\right)$, ear head length $(\mathrm{cm})$, ear head diameter $(\mathrm{cm})$, test weight $(\mathrm{g})$, dry stover yield per plant $(\mathrm{g})$, grain yield per plant (g) and harvest index $(\%)$. The mean data were subjected to analyze combining ability as per the method suggested by Kempthorne (1957).

\section{Results and Discussion}

\section{Combining ability analysis}

The pooled analysis of variance for combining ability (Table 1) showed significant mean sum of squares due to environments, crosses, line $\mathrm{x}$ tester and crosses $\mathrm{x}$ environment for all the characters which indicated presence of significant variations among the material used for study. Mean sum of squares due to lines were found significant for days to maturity, ear head length, ear head diameter, dry stover yield per plant and grain yield per plant while the tester mean sum of squares were found significant for days to $50 \%$ flowering, days to maturity and plant height. Perusal of Table 2 indicated that the magnitude of variance due to GCA was lower as compared to magnitude of SCA for all the characters over the environments which indicated the preponderance of nonadditive components for all the characters over the environments while significant magnitude of variance due to both GCA and 
SCA indicated the importance of both additive and non-additive components in the inheritance of majority of the characters studied. The proportional contribution of lines, testers and their interaction to total variance $(\%)$ over the environments (Table 2 ) showed maximum contribution of lines to total variance for dry stover yield per plant $(50.09 \%)$ followed by ear head diameter $(32.15 \%)$. The maximum contribution of tester to total variance was for plant height (36.79\%) followed by days to $50 \%$ flowering $(33.72 \%)$ and the line $\mathrm{x}$ tester interaction displayed maximum contribution to total variance for number of effective tillers per plant $(81.08 \%)$ followed by total number of tillers per plant $(76.55 \%)$ over the environments. Similar results were also reported in pearl millet by Jeeterwal et al., (2017), Kumar et al., (2017), Solanki et al., (2017) and Badurkar et al., (2018) regarding combining ability and gene actions.

\section{GCA and SCA effects}

The GCA and SCA effects in this section are based on the data pooled over the three environments. The best performing parents (lines and testers) and cross combinations on the basis of GCA and SCA effects (Table 3) revealed that none of the parents was found good general combiner for all the characters which suggested breeding for these characters would be effective when material is tested over a wide range of environments. The female line ICMA 843-22 proved to be good general combiner as it showed significant GCA effects for nine characters namely days to $50 \%$ flowering, days to maturity, plant height, total number of tillers per plant, ear head diameter, test weight, dry stover yield per plant, grain yield per plant and harvest index while RMS 7A was good general combiner for days to maturity, total number of tillers per plant, ear head diameter, dry stover yield per plant and grain yield per plant. ICMA 93333 was good general combiner for days to maturity, total number of tillers per plant, ear head diameter, dry stover yield per plant and grain yield per plant and ICMA 88004 for plant height, test weight and harvest index. The tester or male parent BIB-343 was good general combiner for characters namely days to $50 \%$ flowering, days to maturity total number of tillers per plant, number of effective tillers per plant, ear head length, grain yield per plant and harvest index while BIB-423 for days to $50 \%$ flowering, total number of tillers per plant, number of effective tillers per plant, test weight, dry stover yield per plant, grain yield per plant and harvest index, BIB-451 for days to maturity and grain yield per plant, BIB-383 for days to $50 \%$ flowering, days to maturity, total number of tillers per plant, number of effective tillers per plant and ear head length, BIB-359 for plant height, BIB-407 for plant height, flag leaf area, ear head diameter and dry stover yield per plant and BIB-415 for ear head length and test weight. Krishnan et al., (2017), Ladumor et al., (2018), Saini et al., (2018) and Santosh et al., (2018) also reported various lines and testers having good combining ability behavior for yield and its attributing characters in pearl millet. Top three crosses on the basis of high SCA effects for different characters are presented in Table 3. The cross combinations with significant and high (highest three) SCA effects for at least three or more characters were RMS 7A x BIB-407 for characters namely grain yield per plant, ear head length, ear head diameter and harvest index, ICMA 843-22 x BIB-343 for grain yield per plant, number of effective tillers per plant and total number of tillers per plant, ICMA 88004 x BIB-423 for dry stover yield per plant, number of effective tillers per plant and total number of tillers per plant and ICMA 97111 x BIB 391 for number of effective tillers per plant, total number of tillers per plant and days to $50 \%$ flowering. 
Table.1 ANOVA for combining ability for grain yield per plant and its component traits based on data pooled over all the three environments

\begin{tabular}{|c|c|c|c|c|c|c|c|c|c|c|c|c|c|}
\hline \multirow{2}{*}{$\begin{array}{l}\text { Source of } \\
\text { variation }\end{array}$} & \multirow[t]{2}{*}{ d.f. } & \multicolumn{12}{|c|}{ Mean sum of squares } \\
\hline & & $\begin{array}{c}\text { Days to } \\
50 \% \\
\text { flowering }\end{array}$ & \begin{tabular}{|c|} 
Days to \\
maturity
\end{tabular} & $\begin{array}{c}\text { Plant } \\
\text { height } \\
(\mathrm{cm})\end{array}$ & $\begin{array}{c}\text { Total } \\
\text { no. of } \\
\text { tillers/ } \\
\text { plant }\end{array}$ & $\begin{array}{c}\text { No. of } \\
\text { effective } \\
\text { tillers/ } \\
\text { plant }\end{array}$ & $\begin{array}{c}\text { Flag leaf } \\
\text { area }\left(\mathrm{cm}^{2}\right)\end{array}$ & $\begin{array}{c}\text { Ear } \\
\text { head } \\
\text { length } \\
(\mathrm{cm})\end{array}$ & $\begin{array}{c}\text { Ear } \\
\text { head } \\
\text { diametel } \\
(\mathrm{cm})\end{array}$ & $\begin{array}{r}\text { Te } \\
\text { weigl }\end{array}$ & $\begin{array}{l}\text { Dry stover } \\
\text { yield/ } \\
\text { plant (g) }\end{array}$ & $\begin{array}{c}\text { Grain } \\
\text { yield/ } \\
\text { plant (g) }\end{array}$ & ind \\
\hline $\mathbf{R}$ & 2 & & & & & & & & & & & & \\
\hline Envir & 122 & 295.4 & 634.7 & 5995 & $20.459 *$ & $* 9.889 * *$ & 2479 & 27.5 & & $101 . \varepsilon$ & & & \\
\hline Cros & 49 & 56.5 & & & & & & & & & & & \\
\hline & 4 & 65 & & & & & & & & & & & \\
\hline Tes & 9 & $103.836 *$ & $97.309 *$ & $4278.802 *$ & 3.429 & 1.3 & 06 & 02 & 0 . & 6.542 & 94 & 166.311 & 289 \\
\hline & 36 & $43.806 * *$ & $44.776 * *$ & $1785.183 * *$ & $4.308 * *$ & * $1.686 * *$ & $883.358 * *$ & $48.619 * * 1$ & $\Rightarrow 0.372 * *$ & $4.680 * *$ & 519. & 122.843 ** & 149.538 * \\
\hline & 98 & 4.3 & 3.12 & & & & & & & & & & \\
\hline Error & 294 & 3.298 & 151 & 22.469 & 0.130 & 0.102 & 171.414 & 2.955 & 0.049 & 0.691 & 53.105 & 8.508 & 13.845 \\
\hline
\end{tabular}

$*$ and $* *$ represents significant at $5 \%$ and $1 \%$ level of significance, respectively 
Table.2 Estimates of combining ability variances, genetic components and proportional contribution of lines, testers and their interactions to total variance $(\%)$ for various traits based on data pooled over all the three environments

\begin{tabular}{|c|c|c|c|c|c|c|c|c|c|c|c|c|}
\hline Particulars & $\begin{array}{c}\text { Days to } \\
50 \% \\
\text { flowering }\end{array}$ & $\begin{array}{l}\text { Days to } \\
\text { maturity }\end{array}$ & $\begin{array}{c}\text { Plant } \\
\text { height } \\
\text { (cm) }\end{array}$ & $\begin{array}{c}\text { Total } \\
\text { no. of } \\
\text { tillers/ } \\
\text { plant }\end{array}$ & $\begin{array}{c}\text { No. of } \\
\text { effective } \\
\text { tillers/ } \\
\text { plant }\end{array}$ & $\begin{array}{l}\text { Flag } \\
\text { leaf } \\
\text { area } \\
\left(\mathrm{cm}^{2}\right)\end{array}$ & $\begin{array}{l}\text { Ear } \\
\text { head } \\
\text { length } \\
(\mathrm{cm})\end{array}$ & $\begin{array}{l}\text { Ear head } \\
\text { diameter } \\
(\mathrm{cm})\end{array}$ & $\begin{array}{c}\text { Test } \\
\text { weight } \\
\text { (g) }\end{array}$ & $\begin{array}{l}\text { Dry } \\
\text { stover } \\
\text { yield/ } \\
\text { plant } \\
\text { (g) }\end{array}$ & $\begin{array}{c}\text { Grain } \\
\text { yield/ } \\
\text { plant } \\
(\mathrm{g})\end{array}$ & $\begin{array}{c}\text { Harvest } \\
\text { index } \\
(\%)\end{array}$ \\
\hline$\sigma_{\text {gca }}^{2}$ & 1.202 & 1.767 & 34.879 & 0.054 & 0.012 & 15.372 & 1.341 & 0.013 & 0.072 & 41.032 & 5.870 & 3.018 \\
\hline$\sigma_{\text {sca }}^{2}$ & 4.501 & 4.736 & 195.857 & 0.464 & 0.176 & 79.105 & 5.074 & 0.036 & 0.443 & 51.785 & 12.704 & 15.077 \\
\hline$\sigma_{\text {gca }}^{2} / \sigma_{\text {sca }}^{2}$ & 0.267 & 0.373 & 0.178 & 0.116 & 0.068 & 0.194 & 0.264 & 0.361 & 0.163 & 0.792 & 0.462 & 0.200 \\
\hline$\sigma_{A}^{2}$ & 2.404 & 3.535 & 69.758 & 0.109 & 0.024 & 30.744 & 2.681 & 0.026 & 0.145 & 82.063 & 11.739 & 6.035 \\
\hline$\sigma_{D}^{2}$ & 4.501 & 4.736 & 195.857 & 0.464 & 0.176 & 79.105 & 5.074 & 0.036 & 0.443 & 51.785 & 12.704 & 15.077 \\
\hline$\sigma_{A}^{2} / \sigma_{D}^{2}$ & 0.534 & 0.746 & 0.356 & 0.234 & 0.134 & 0.389 & 0.528 & 0.734 & 0.326 & 1.585 & 0.924 & 0.400 \\
\hline Lines (I) & 9.386 & 18.967 & 1.814 & 8.214 & 2.101 & 16.380 & 19.025 & 32.154 & 7.479 & 50.093 & 30.294 & 14.827 \\
\hline Testers (t) & 33.717 & 28.527 & 36.789 & 15.234 & 16.820 & 12.093 & 17.853 & 5.805 & 23.960 & 6.176 & 17.627 & 16.553 \\
\hline $\mathbf{l} \times t$ & 56.897 & 52.506 & 61.396 & 76.552 & 81.080 & 71.527 & 63.123 & 62.041 & 68.562 & 43.731 & 52.080 & 68.621 \\
\hline
\end{tabular}


Table.3 Best performing parents (lines and testers) and crosses on the basis of GCA and SCA effects over the environments

\begin{tabular}{|c|c|c|c|}
\hline \multirow[t]{2}{*}{ Characters } & \multicolumn{2}{|c|}{ Parents } & \multirow[t]{2}{*}{ Crosses } \\
\hline & Lines & Testers & \\
\hline Days to $50 \%$ flowering & 1. ICMA $842-22$ & $\begin{array}{ll}\text { 1. } & \text { BIB-343 } \\
\text { 2. } & \text { BIB-383 } \\
\text { 3. } & \text { BIB-423 }\end{array}$ & $\begin{array}{ll}\text { 1. } & \text { RMS 7A x BIB-359 } \\
\text { 2. } & \text { ICMA } 97111 \times \text { BIB-391 } \\
\text { 3. } & \text { ICMA } 93333 \times \text { BIB-407 }\end{array}$ \\
\hline Days to maturity & $\begin{array}{ll}\text { 1. } & \text { RMS 7A } \\
\text { 2. ICMA 843-22 }\end{array}$ & $\begin{array}{ll}\text { 1. } & \text { BIB-343 } \\
\text { 2. } & \text { BIB- } 451 \\
\text { 3. } & \text { BIB-383 }\end{array}$ & $\begin{array}{ll}\text { 1. } & \text { RMS 7A x BIB-359 } \\
\text { 2. } & \text { ICMA } 88004 \times \text { BIB-343 } \\
\text { 3. } & \text { ICMA } 93333 \times \text { BIB-415 }\end{array}$ \\
\hline Plant height (cm) & $\begin{array}{ll}\text { 1. ICMA } 88004 \\
\text { 2. }\end{array}$ & $\begin{array}{ll}\text { 1. } & \text { BIB-359 } \\
\text { 2. } & \text { BIB-407 } \\
\text { 3. } & \text { BIB-415 }\end{array}$ & $\begin{array}{ll}\text { 1. } & \text { RMS 7A x BIB-391 } \\
\text { 2. } & \text { ICMA } 843-22 \times \text { BIB-359 } \\
\text { 3. } & \text { ICMA } 88004 \times \text { BIB-415 }\end{array}$ \\
\hline Total number of tillers per plant & $\begin{array}{l}\text { 1. ICMA 843-22 } \\
\text { 2. RMS 7A }\end{array}$ & $\begin{array}{ll}\text { 1. } & \text { BIB-343 } \\
\text { 2. } & \text { BIB-383 } \\
\text { 3. } & \text { BIB- } 423\end{array}$ & $\begin{array}{ll}\text { 1. } & \text { ICMA } 88004 \times \text { BIB-423 } \\
\text { 2. ICMA } 97111 \times \text { BIB-391 } \\
\text { 3. ICMA } 843-22 \times \text { BIB-343 }\end{array}$ \\
\hline Number of effective tillers per plant & - & $\begin{array}{ll}\text { 1. } & \text { BIB- } 423 \\
\text { 2. } & \text { BIB-343 } \\
\text { 3. } & \text { BIB-383 }\end{array}$ & $\begin{array}{ll}\text { 1. } & \text { ICMA } 88004 \times \text { BIB-423 } \\
\text { 2. ICMA } 97111 \times \text { BIB-391 } \\
\text { 3. ICMA } 843-22 \times \text { BIB-343 }\end{array}$ \\
\hline Flag leaf area $\left(\mathrm{cm}^{2}\right)$ & 1. ICMA 93333 & 1. $\mathrm{BIB}-407$ & $\begin{array}{ll}\text { 1. } & \text { ICMA } 88004 \times \text { BIB-391 } \\
\text { 2. } & \text { ICMA } 97111 \times \text { BIB-383 } \\
\text { 3. } & \text { RMS 7A x BIB-343 }\end{array}$ \\
\hline Ear head length (cm) & 1. ICMA 93333 & $\begin{array}{ll}\text { 1. } & \text { BIB-383 } \\
\text { 2. } & \text { BIB-343 } \\
\text { 3. } & \text { BIB- } 415\end{array}$ & $\begin{array}{ll}\text { 1. } & \text { ICMA } 843-22 \times \text { BIB-415 } \\
\text { 2. } & \text { RMS 7A } \times \text { BIB-407 } \\
\text { 3. } & \text { RMS 7A x BIB-451 }\end{array}$ \\
\hline Ear head diameter $(\mathrm{cm})$ & $\begin{array}{ll}\text { 1. } & \text { RMS 7A } \\
\text { 2. ICMA 843-22 }\end{array}$ & 1. $\mathrm{BIB}-407$ & $\begin{array}{ll}\text { 1. } & \text { RMS 7A x BIB-407 } \\
\text { 2. } & \text { ICMA } 97111 \times \text { BIB-343 } \\
\text { 3. } & \text { ICMA } 97111 \times \text { BIB-359 }\end{array}$ \\
\hline Test weight (g) & $\begin{array}{ll}\text { 1. } & \text { ICMA } 88004 \\
\text { 2. } & \text { ICMA } 843-22\end{array}$ & $\begin{array}{ll}\text { 1. } & \text { BIB- } 415 \\
\text { 2. } & \text { BIB- } 423\end{array}$ & $\begin{array}{ll}\text { 1. } & \text { ICMA } 843-22 \times \text { BIB-451 } \\
\text { 2. } & \text { RMS 7A x BIB-383 } \\
\text { 3. } & \text { ICMA } 97111 \times \text { BIB-407 }\end{array}$ \\
\hline Dry stover yield per plant (g) & $\begin{array}{ll}\text { 1. } & \text { RMS 7A } \\
\text { 2. ICMA 843-22 }\end{array}$ & $\begin{array}{ll}\text { 1. } & \text { BIB-407 } \\
\text { 2. } & \text { BIB- } 423\end{array}$ & $\begin{array}{ll}\text { 1. } & \text { ICMA } 88004 \times \text { BIB-423 } \\
\text { 2. } & \text { ICMA } 843-22 \times \text { BIB-359 } \\
\text { 3. } & \text { ICMA } 93333 \times \text { BIB-439 }\end{array}$ \\
\hline Grain yield per plant (g) & $\begin{array}{l}\text { 1. ICMA 843-22 } \\
\text { 2. RMS 7A }\end{array}$ & $\begin{array}{ll}\text { 1. } & \text { BIB- } 423 \\
\text { 2. } & \text { BIB- }-343 \\
\text { 3. } & \text { BIB- } 451\end{array}$ & $\begin{array}{ll}\text { 1. } & \text { RMS 7A x BIB-407 } \\
\text { 2. } & \text { ICMA } 843-22 \times \text { BIB-343 } \\
\text { 3. } & \text { ICMA } 843-22 \times \text { BIB-451 }\end{array}$ \\
\hline Harvest index (\%) & $\begin{array}{l}\text { 1. ICMA } 843-22 \\
\text { 2. ICMA } 88004\end{array}$ & $\begin{array}{ll}\text { 1. } & \text { BIB-343 } \\
\text { 2. } & \text { BIB- } 423\end{array}$ & $\begin{array}{ll}\text { 1. } & \text { RMS 7A x BIB-407 } \\
\text { 2. ICMA } 97111 \times \text { BIB-399 } \\
\text { 3. ICMA } 88004 \times \text { BIB-391 }\end{array}$ \\
\hline
\end{tabular}


Table.4 Hybrids showing significant positive specific combining ability effects for grain yield along with per se performance (g) and their performance in other traits

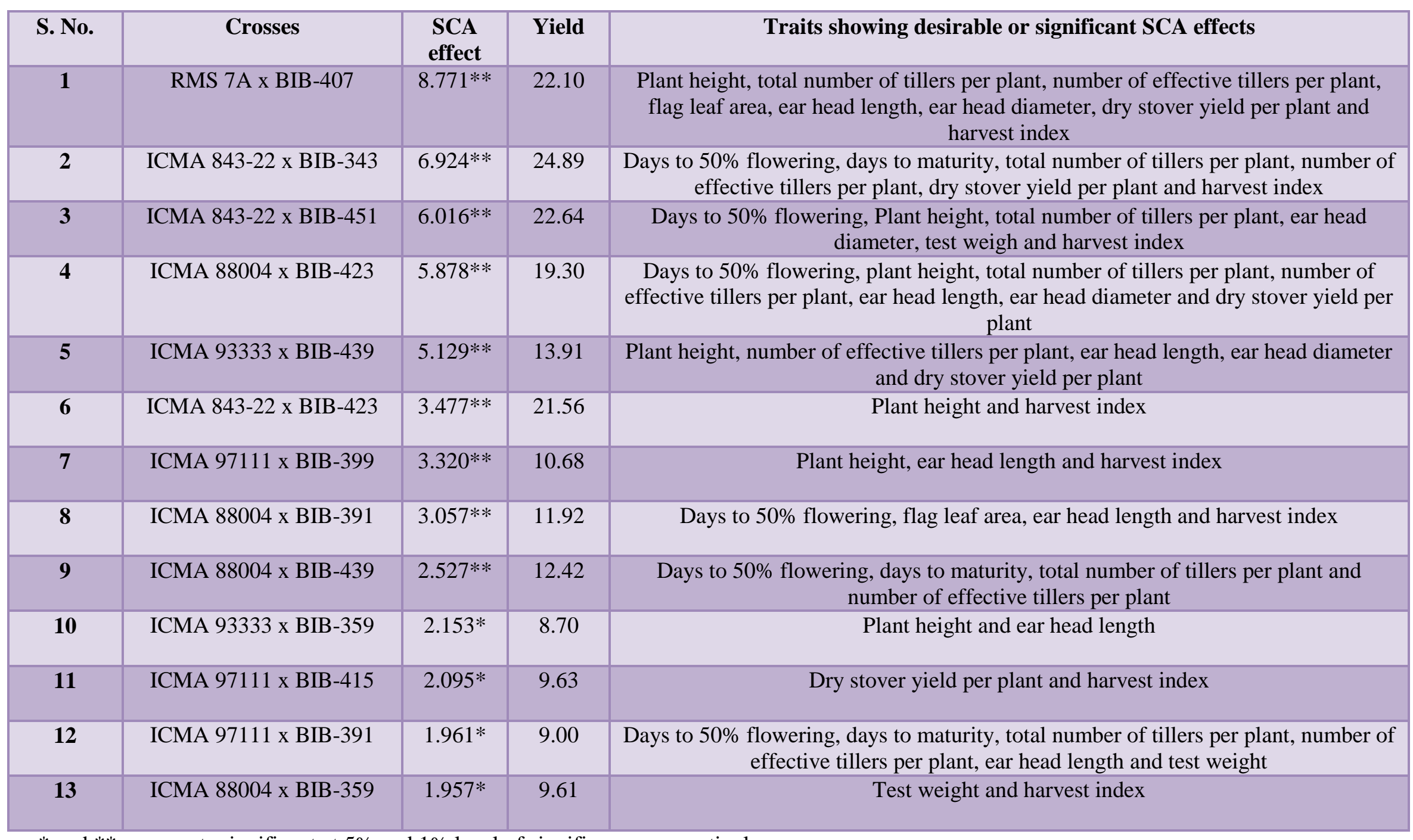

$*$ and $* *$ represents significant at $5 \%$ and $1 \%$ level of significance, respectively 
Singh and Sharma (2014), Eldie et al., (2017), Siddique et al., (2017), Gavali et al., (2018) and Ladumor et al., (2018) also reported some specific combiners for yield and its contributing characters in pearl millet. The cross RMS 7A x BIB-407 proved as best specific combiner over the environments for nine characters like grain yield per plant, dry stover yield per plant, harvest index, plant height, total number of tillers per plant, number of effective tillers per plant, flag leaf area, ear head length and ear head diameter followed by ICMA 88004 x BIB-423 for eight characters like days to $50 \%$ flowering, plant height, total number of tillers per plant, number of effective tillers par plant, ear head length, ear head diameter, dry stover yield per plant and grain yield per plant. Out of total 50 crosses analyzed, 13 crosses showed positive significant SCA effects for grain yield per plant over the environments which are presented in Table 4 along with per se performance and traits also showing positive and significant SCA effects along with grain yield per plant. Out of which RMS 7A x BIB407, ICMA 843-22 x BIB-343 and ICMA 843-22 x BIB-451 were found to be best top three performers for grain yield per plant and some of the component characters. Gavali et al., (2018), Ladumor et al., (2018) and Saini et al., (2018) also reported some specific combiners for pearl millet on the basis of SCA effects.

In conclusion, the ratio of additive to dominance variance was less than unity for all the traits except dry stover yield per plant over the environments which indicated the preponderance of non-additive gene action in the inheritance of majority of the characters. Hence, recurrent selection or mass selection may be adopted for population improvement to exploit additive gene action in the present material and heterosis breeding may be adopted to exploit non-additive gene action for improving yield in pearl millet. GCA effects revealed that parents namely ICMA 843-22, RMS 7A (female parents), BIB-423, BIB-343, BIB-451 and BIB-407 (male parents) were good general combiners for grain yield per plant and some other attributes and can be utilized for development of synthetic populations in pearl millet. Amongst the total 50 crosses evaluated, the five crosses namely ICMA 843-22 x BIB-343, ICMA 843$22 \times$ BIB-451, RMS 7A x BIB-407, ICMA 843-22 x BIB-423 and ICMA 88004 x BIB423 exhibited high per se performance and high significant SCA effects over the environments as well as in limited moisture conditions $\left(E_{2}\right.$ and $\left.E_{3}\right)$ for many character along with grain yield per plant. Thus, these parents can be used to develop hybrids suitable for dry areas and single cross hybrids may be included in multi-locational testing programme to identify the suitability as commercial hybrid in arid and semi-arid regions for high yield and its attributing characters.

\section{References}

Badurkar, S.B., Pole, S.P., Toprope, V.N. and Ingle, N.P. 2018. Combining ability for grain yield and its related traits in pearl millet (Pennisetum glaucum L.). International Journal of Current Microbiology and Applied Sciences. 6: 956-961.

Burton, G.W. 1965. Pearl millet Tift 23A released. Crop Soil. 17: 19.

Burton, G.W., Wallance, A.T. and Rachie, K.O. 1972. Chemical composition and nutritive value of pearl millet [Pennisetum glaucum (L.) R. Br.] grain. Crop Sci. 2(2):187-189.

Eldie, Y.D., Ibrahim, A.E.S. and Ali, A.M. 2009. Combining ability analysis for grain yield and its components in pearl millet. Gezira Journal of Agricultural Science. 7(1): 1-10.

Flech, H. 1981. Introduction to nutrition. Mac 
Millan Publishing Co. India, pp 49

Gavali, R.K., Kute, N.S., Pawar, V.Y. and Patil, H.T. 2018. Combining ability analysis and gene action studies in pearl millet [Pennisetum glaucum (L.) R. Br.]. Electronic Journal of Plant Breeding. 9(3): 908-915.

Jeeterwal, R.C., Sharma, L.D. and Nehra, A. 2017. Combining ability studies through diallel analysis in pearl millet [Pennisetum glaucum (L.) R.Br.] under varying environmental conditions. Journal of Pharmacognosy and Phytochemistry. 6(4): 1083-1088.

Kempthorne, O. 1957. An introduction to genetic statistics. John Wiley and Sons Inc. New York, pp 458-471.

Krishnan, M.R.R., Patel, M.S., Gami, R.A., Bhadauria, H.S. and Patel, Y.N. 2017. Genetic analysis in pearl millet [Pennisetum glaucum (L.) R. Br.]. Int. J. Curr. Microbiol. App. Sci. 6(11): 900907.

Kumar, M., Gupta, P.C., Kumar, P. and Barupal, H. 2017. Assessment of combining ability and gene action for grain yield and its component traits in pearl millet [Pennisetum glaucum (L.) R. Br.]. Journal of Pharmacognosy and Phytochemistry. 6(3): 431-434.

Ladumor, V.L., Mungra, K.D., Parmar, S.K., Sorathiya, J.S. and Vansjaliya, H.G. 2018. Grain iron, zinc and yield genetics in pearl millet (Pennisetum glaucum L. R. Br.). Int. J. Curr. Microbiol. App. Sci. 7(9): 242-250.

Saini, L.K., Solanki, K.L., Gupta, P.C., Saini, H. and Singh, A.G. 2018. Combining ability studies for grain yield and component traits in pearl millet [Pennisetum glaucum (L.) R. Br.]. International Journal of Chemical Studies. 6(1): 1939-1944.

Santosh, T., Sadhana, K., Reddy, G.A. and Patil, H.T. 2018. Assessment of combining ability and gene action in pearl millet (Pennisetum glaucum (L.) $\mathrm{R}$. Br.) using line $\mathrm{x}$ tester analysis. International Journal of Pure \& Applied Bioscience. 6(2): 172-177.

Siddique, M., Irshad-Ul-Haq, M., Khanum, S., Kamal, N. and Ullah, M.A. 2017. Combining ability studies of grain yield and related traits in pearl millet. Research in Plant Biology. 7: 21-23.

Singh, J. and Sharma, R. 2014. Assessment of combining ability in pearl millet using line $\mathrm{x}$ tester analysis. Advances in Crop Science and Technology. 2(4): 1-4.

Solanki, K.L., Bhinda, M.S., Gupta, P.C., Saini, H. and Saini, L.K. 2017. Combining ability and gene action studies for grain yield and component characters in pearl millet [Pennisetum glaucum (L.) R. Br.] under arid condition of Rajasthan. International Journal of Pure and Applied Bioscience. 5 (4): 2121-2129.

\section{How to cite this article:}

Kana Ram Kumawat, P.C. Gupta and Sharma, N.K. 2019. Combining Ability and Gene Action Studies in Pearl Millet using Line $\mathrm{x}$ Tester Analysis under Arid Conditions. Int.J.Curr.Microbiol.App.Sci. 8(04): 976-984. doi: https://doi.org/10.20546/ijcmas.2019.804.113 